\title{
SURVEI SIDE SCAN SONAR DALAM PENELITIAN ARKEOLOGI BAWAH AIR DI PERAIRAN SUNGAI: STUDI KASUS PADA DAERAH ALIRAN SUNGAI BRANTAS
}

\section{SIDE SCAN SONAR SURVEY IN RIVERINE UNDERWATER ARCHAEOLOGICAL RESEARCH: CASE STUDY IN THE BRANTAS BASIN}

\author{
Agni Sesaria Mochtar1, Firman Setiawan², dan Shinatria Adityatama ${ }^{3}$ \\ ${ }^{1}$ Balai Arkeologi Provinsi D.I. Yogyakarta, Jl. Gedongkuning No.174, Rejowinangun, Kec. Kotagede, Kota Yogyakarta, Daerah \\ Istimewa Yogyakarta, Indonesia; posel: mochtar.agni@gmail.com \\ 2Oseawan Geotama Surveindo, Bumi Sukagalih Permai Blok B1 No.38 Katapang, Kabupaten Bandung, Indonesia; posel: \\ firmansetiawan08@gmail.com \\ ${ }^{3}$ Griffith University, Queensland, Griffith Centre for Social and Cultural Research, Griffith University \\ Parklands Dr, Southport, Gold Coast, QLD, Australia; posel: shinatriaadhityatama@gmail.com
}

\begin{abstract}
Abstrak. Aplikasi metode geofisika menggunakan side scan sonar dalam penelitian arkeologi bawah air belum banyak dilakukan di Indonesia. Tulisan ini memaparkan penggunaan side scan sonar untuk pemetaan dasar sungai dan identifikasi tinggalan arkeologi di dasar sungai dalam penelitian "Sungai Brantas dalam Perspektif Lanskap Kultur Maritim", serta interpretasi hasil survei side scan sonar tersebut dalam konteks kesejarahan. Selain itu, dalam tulisan ini akan dibahas potensi pengembangan penggunaan side scan sonar dalam penelitian arkeologi bawah air di Indonesia, terutama di perairan sungai. Akuisisi data dilakukan dengan menggunakan side scan sonar Starfish 450H dengan sistem posisi GNSS Trimble R8s. Sementara itu, interpretasi diperoleh dengan melakukan analisis terhadap data peta dan arsip Belanda untuk memahami konteks temporal dari objek yang dideteksi oleh alat side scan sonar. Survei berhasil menunjukkan sedimen di dasar sungai berupa lempung dan lanau, serta beberapa objek yang diduga sebagai bangkai kapal, yang diperkirakan berasal dari pasca abad ke-19 Masehi. Hasil survei side scan sonar menunjukkan tingkat akurasi cukup hingga tinggi dan dapat menjadi pendukung penelitian arkeologi bawah air yang efisien, terutama di perairan yang keruh.
\end{abstract}

Kata kunci: Side scan sonar, Sungai Brantas, Arkeologi bawah air, Sistem posisi, Lanskap budaya maritim

\begin{abstract}
Side scan sonar survey as one of the geophysics methods is still scarcely applied in underwater archaeological research in Indonesia. This paper describes the application of side scan sonar survey in mapping riverbed and identifying underwater archaeological remains in the "Sungai Brantas in the Perspective of Maritime Cultural Landscape" project, as well as interpreting its historical context based on survey results. This paper also explores the development of utilizing side scan sonar in underwater archaeological research in Indonesia, particularly in rivers. Data was acquisitioned by using the side scan sonar Starfish $450 \mathrm{H}$ and GNSS Trimble R8s positioning system. The interpretation was drawn by analysing related Dutch old maps and archives to understand the historical context of the survey findings. The result shows clay and silt sediment covering most of the riverbed and a number of objects, possibly shipwrecks, estimated as from the nineteenth century. The survey result has a medium to high accuracy. Thus, this method is able to serve as an efficient instrument for underwater archaeological research, especially in the low-visibility waters.
\end{abstract}

Keywords: Side scan sonar, Brantas River, Underwater archaeology, Positioning system, Maritime cultural landscape

\section{PENDAHULUAN}

Penelitian arkeologi bawah air seringkali menghadapi tantangan dalam hal kondisi lokasi penelitian yang tidak ideal. Beberapa contoh di antaranya adalah posisi tinggalan arkeologi di laut dalam, rendahnya visibilitas air, dan terbatasnya jumlah penyelaman yang bisa dilakukan (Hobbs dkk 1994; Staniforth 2009). Hal ini kemudian mendorong mulai digunakannya berbagai metode dari disiplin ilmu lain sebagai instrumen penelitian. Salah satu di antaranya adalah metode pengindraan dengan sonar yang dikembangkan dalam ilmu geofisika, seperti side scan sonar, single beam, multibeam, dan sub-bottom profiler. Secara umum metode survei tersebut mampu memberikan gambaran kondisi di dasar perairan tanpa perlu dilakukan penyelaman langsung (Flemming 1976; Singh dkk 2000).

Di Indonesia sendiri metode survei pengindraan sonar masih sangat jarang digunakan dalam penelitian arkeologi bawah air, terutama dengan alasan tingginya biaya operasional metode tersebut. Beberapa survei potensi tinggalan arkeologi bawah air yang telah dilakukan di Indonesia hampir seluruhnya dilakukan di laut. 
Salah satunya adalah Gemilang dkk (2020), yang melaporkan hasil identifikasi tinggalan arkeologi bawah air di perairan laut Pontianak, Kalimantan Barat dengan menggunakan side scan sonar. Dengan menggunakan Starfish 452F dan Echosounder Hi-Sounder HD-380, tim ini berhasil menemukan titik lokasi kapal tenggelam pada kedalaman 27-33 m di bawah permukaan laut, yang diduga berkaitan dengan aktivitas Kesultanan Melayu. Dillenia dan Troa (2016) juga menggunakan side scan sonar untuk indentifikasi tinggalan arkeologi bawah air di dasar laut ketika melakukan identifikasi situs kapal karam "Karang Panjang" di perairan Pulau Laut, Natuna. Survei dengan side scan sonar dilakukan untuk mengindentifikasi bagian-bagian kapal, seperti haluan, buritan, cerobong, dan baling-baling. Hosty, Hunter, dan Adhityatama (2018) juga menggunakan side scan sonar yang dikombinasikan dengan multibeam echosounder, untuk survei tinggalan kapal Perang Dunia ke-2 situs HMAS Perth karena keterbatasan jarak pandang dan kuatnya arus laut yang menyebabkan kesulitan dalam mengobservasi bagian kapal. Hasil survei ini kemudian dikonfirmasi dengan melakukan observasi langsung dengan penyelaman. Sementara itu, belum pernah dilakukan survei tinggalan arkeologi bawah air di perairan sungai.

Penerapan metode penginderaan sonar sebenarnya dapat menjadi salah satu solusi sulitnya melaksanakan penelitian bawah air di berbagai perairan di Indonesia, tetapi hingga kini belum dikembangkan strategi efektif dan efisien untuk penerapan metode tersebut dalam penelitian arkeologi bawah air di Indonesia. Oleh karena itu, tulisan ini akan membahas penerapan salah satu metode pengindraan sonar, yaitu side scan sonar, dalam penelitian arkeologi arkeologi bawah air di perairan sungai serta melakukan evaluasi penerapan metode tersebut sebagai acuan pelaksanaan penelitian sejenis di kemudian hari.

Side scan sonar merupakan sebuah sistem peralatan survei kelautan dengan teknologi akustik yang mampu melakukan pencitraan bawah perairan dan menghasilkan berbagai variasi gambar benda/objek di dasar perairan (Hobbs dkk 1994). Penerapan visual lingkungan dasar perairan dengan side scan sonar telah menjadi solusi pilihan untuk pengamatan dasar laut sejak tahun 1950-an (Blondel 2002 dalam Coiras dan Groen 2009). Hasil perekaman side scan sonar memberikan suatu gambar dari dasar perairan dengan resolusi tinggi secara jelas sehingga memudahkan dalam interpretasi kondisi dasar perairan dan objek yang ada. Hasil pencitraan side scan sonar disajikan dalam bentuk dua dimensi (2D) (Wijonarko dan Sasmito 2016).

Prinsip dasar side scan sonar adalah menggunakan gelombang suara untuk mendeteksi atau menemukan objek yang secara khusus berada di dasar perairan (Hansen 2011). Frekuensi digital ganda dalam perangkat side scan sonar menghasilkan gambar yang hampir realistis. Metode visualisasi digunakan untuk membantu interpretasi dan membedakan besar-kecil objek dan partikel penyusun permukaan dasar perairan, seperti batuan, lumpur, pasir, kerikil, atau tipe-tipe dasar perairan dan objek-objek lainnya (Bartholomä 2006). Side scan sonar digunakan untuk berbagai kegunaan, seperti pendeteksian keberadaan pipa dan kabel laut, pendeteksian struktur dangkal dasar laut, pelaksanaan pengerukan, studi lingkungan, kemiliteran, arkeologi, perikanan, serta pertambangan (Manik 2011).

Berdasarkan karakteristik dan kegunaannya, side scan sonar dipilih sebagai metode geofisika yang diterapkan dalam penelitian berjudul "Sungai Brantas dalam Perspektif Lanskap Kultur Maritim". Penelitian ini adalah penelitian arkeologi maritim yang menggabungkan survei arkeologi di darat dengan survei arkeologi bawah air. Permasalahan yang dibahas dalam penelitian ini adalah tinggalan arkeologi apa yang terdapat di sepanjang Sungai Brantas, serta bagaimanakah tinggalan arkeologi tersebut membentuk sebuah lanskap kultur maritim di wilayah DAS Brantas? Tujuan dari penelitian ini adalah untuk mempelajari peran Sungai Brantas pada masa lalu dalam menghubungkan wilayah pedalaman dengan wilayah pesisir.

Penelitian arkeologi maritim dengan pendekatan lanskap kultur maritim masih sangat jarang dilakukan di Indonesia. Pendekatan ini diperkenalkan oleh Westerdahl (1992) dengan mengedepankan ide bahwa tinggalan arkeologi di dasar laut memiliki kesatuan kognitif dengan tinggalan arkeologi di darat. Salah satu aspek dalam pendekatan lanskap kultur maritim ini adalah proses peralihan dari sistem lautan lepas ke sistem sungai. Penelitian maritim di Sungai Brantas ini adalah salah satu dari sedikit penelitian lanskap kultur maritim di Indonesia dan termasuk yang pertama menerapkannya pada sistem sungai.

Pengumpulan data dalam penelitian ini dilaksanakan dengan melakukan survei. Survei yang dilakukan meliputi survei tinggalan arkeologi di sepanjang Sungai Porong yang merupakan salah satu anak Sungai Brantas, survei tinggalan arkeologi di dasar Sungai Porong, dan survei tinggalan arkeologi di sekitar muara Sungai Porong di Selat Madura (Mochtar dkk 2019). Survei side scan sonar dilakukan untuk mendeteksi 
tinggalan arkeologi di dasar perairan sungai di Sungai Porong (Gambar 1). Sebelumnya penelitian arkeologi tentang Sungai Brantas telah cukup banyak dilakukan, tetapi masih terfokus pada baik tinggalan arkeologi darat maupun kajian epigrafi. Seperti kajian tentang transportasi air digunakan dalam aktivitas perdagangan masa Jawa Kuno di Jawa Timur berdasarkan data prasasti. Kajian tersebut mengidentifikasi berbagai jenis moda transportasi air yang digunakan di laut lepas, serta di aliran sungai seperti Sungai Brantas (Hedwi 2014). Selain itu, telaah atas data prasasti juga dilakukan untuk mengetahui penanganan bencana banjir pada abad ke-11 M berhasil memulihkan jalur lalu lintas perahu di Sungai Brantas (Sandi dan Pamungkas 2015).

Dalam penelitian ini dilakukan survei di dasar sungai langsung untuk mengetahui adanya tinggalan arkeologi di dasar Sungai Brantas yang diperkirakan sebagai bukti langsung ramainya aktivitas di sungai tersebut pada masa lalu. Hal ini belum pernah dilakukan dalam penelitian arkeologi sebelumnya. Survei side scan sonar dilakukan di Sungai Porong yang merupakan salah satu anak Sungai Brantas. Side scan sonar dipilih karena kondisi air di Sungai Porong yang tidak mendukung dilakukannya survei arkeologi bawah air dengan teknik penyelaman. Tingkat kejernihan air yang sangat rendah sehingga jarak pandang sangat dekat $(>50 \mathrm{~cm}$ ) dan tingkat polusi yang sangat tinggi (Yuniar, Suharso, dan Prayitno 2010) membahayakan para penyelam. Titik ikat survei berada di dermaga wisata Tlocor pada koordinat $70^{\circ} 33^{\prime} 34.2^{\prime \prime}$ LS dan 112 $51^{\prime}$ '26.64" BT. Dari titik ikat tersebut, survei dilakukan ke arah hulu sejauh 8 kilometer $(\mathrm{km})$ dan ke arah hilir sampai muara Sungai Porong di Selat Madura (Gambar 2).

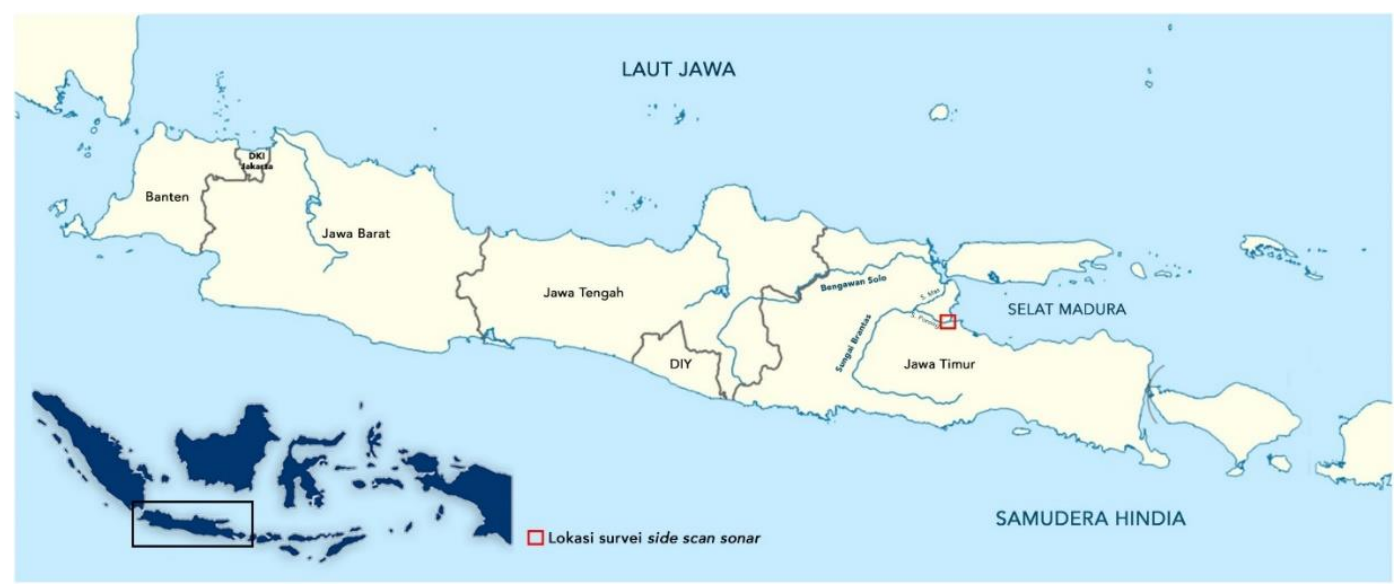

Sumber: NordNordWest, dengan modifikasi penulis 2021

Gambar 1 Lokasi Penelitian

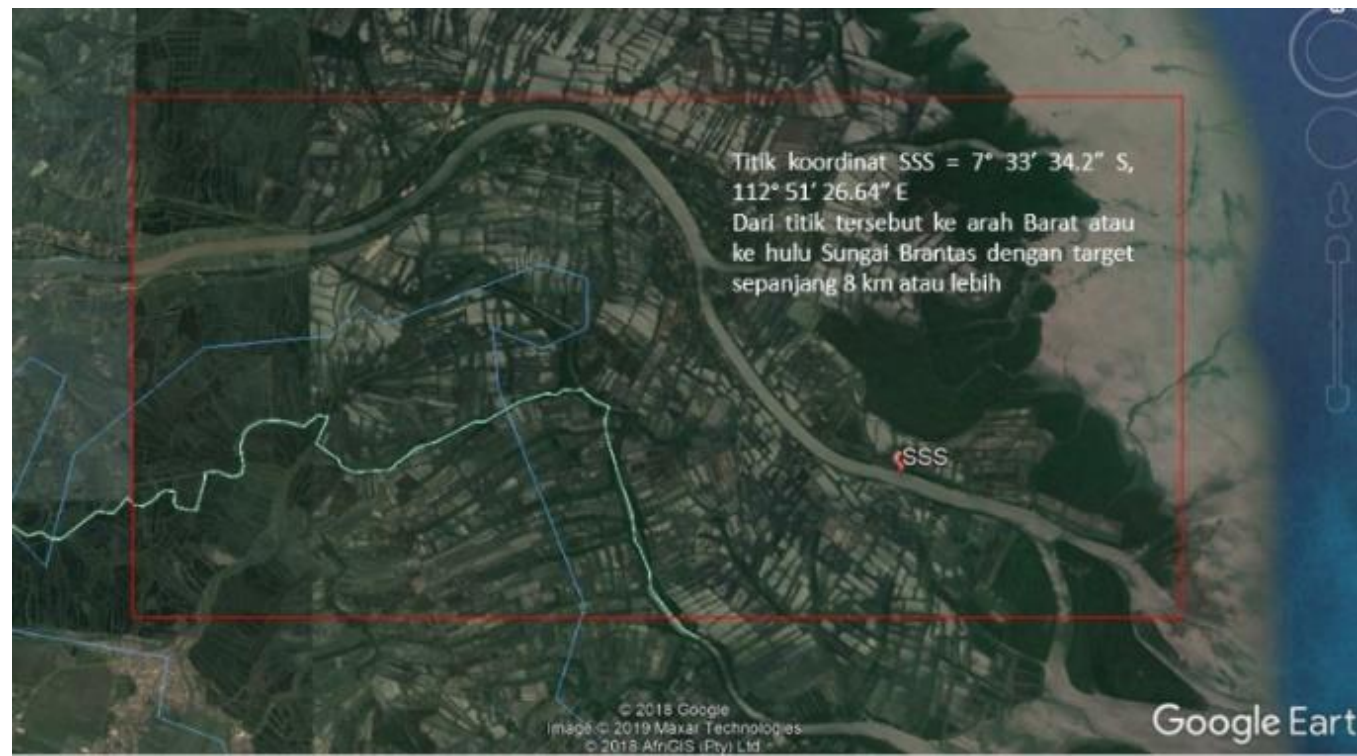

Sumber: Google, Maxar Technology, dengan modifikasi penulis 2019

Gambar 2 Posisi Titik Ikat dan Jalur Survei Side Scan Sonar 


\section{METODE}

\section{Perangkat Survei}

Pengambilan data di lapangan dilakukan menggunakan side scan sonar Starfish $450 \mathrm{H}$ dengan sistem posisi menggunakan GNSS Trimble R8s metode RTK (Real Time Kinematic) yang terpasang pada kapal. Alat dioperasikan dengan menggunakan seperangkat komputer untuk merekam data secara real time dengan perangkat lunak akuisisi data, yaitu Scanline dan perangkat lunak navigasi, yaitu Hydropro Navigation. Sistem side scan sonar Starfish $450 \mathrm{H}$ memiliki satu frekuensi $450 \mathrm{kHz}$ yang mampu memetakan dan mengklasifikasikan dasar suatu perairan dengan gambar yang detail (Tabel 1). Sementara data batimetri yang berupa tinggirendahnya dasar perairan, diperoleh dengan menggunakan Garmin MapSounder 585. Data batimetri memberikan informasi tentang permukaan dasar perairan.

Data mentah hasil akuisisi survei side scan sonar tersimpan dalam format .xtf dan .logdoc. Kemudian data tersebut diolah menggunakan perangkat lunak SonarWiz dan untuk pemetaan digunakan perangkat lunak Global Mapper 15/Arc GIS 10.1.

Tabel 1 Spesifikasi Side scan sonar Starfish $450 \mathrm{H}$

\begin{tabular}{ll}
\hline Frequency & $450 \mathrm{kHz}$ CHIRP \\
Operating Range & $100 \mathrm{~m}(328 \mathrm{ft})$ per channel \\
Horizontal Beam Width & 1.70 \\
Vertical Beam Width & $60^{\circ}$ \\
Depth Rating & $50 \mathrm{~m}(164 \mathrm{ft})$ \\
Pulse Length & $400 \mu \mathrm{s} \mathrm{typical.}$ \\
Transmit Source Power Level & $<210 \mathrm{~dB}$ re $1 \mathrm{~Pa} @ 1 \mathrm{~m}$. \\
Application & Law Enforcement/ Homeland Security, Wreck Location/Archaeology \\
& Survey, Engineering, Dive Clubs, Academic/ Research, Angling/Fishing \\
\hline
\end{tabular}

Sumber: (www.Tritech.co.uk/TritechStarfish)

\section{Metode}

Secara garis besar tahapan dari pengolahan data yang dilakukan adalah seperti pada diagram alir pada Gambar 3. Prinsip side scan sonar adalah saat sinyal ditransmisikan merambat dalam air, transducer sonar dapat menerima noise dan echo. Echo dasar perairan yang menghasilkan pantulan pertama sangat kuat sebagai kekuatan backscatter maksimal dan kerugian transmisi yang minimal. Efek dalam pembentukan bayangan dari dasar laut dapat terjadi dan akan mencegah terjadinya backscattering dari dasar perairan yang terhalang bayangan tersebut. Echo yang dihasilkan biasanya sangat rendah dan akan menghasilkan gambar sonar sama dengan bayangan obyek, analisis ini akan memberikan perkiraan ukuran dan bentuk objek (McCauley dan Siwabessy 2005). Pancaran sinyal suara yang dipancarkan oleh transducer yang berinteraksi dengan dasar laut pada sudut miring, sejumlah energi terpancar dari transducer dan sebagian dipantulkan kembali ke transducer oleh objek di dasar laut. Energi yang dipantulkan kembali ini dikenal sebagai backscatter akustik (McCauley dan Siwabessy 2005).

Selain real-time processing, juga dapat dilakukan post-processing, yaitu pengolahan data citra side scan sonar dalam bentuk interpretasi. Proses interpretasi dapat menghasilkan citra yang baik bila citra tersebut telah dilakukan koreksi dari data mentah citra side scan sonar yang didapat. Koreksi-koreksi tersebut terdiri atas koreksi bottom track, navigation correction, dan gain control. Interpretasi terhadap citra side scan sonar dapat dilakukan secara kualitatif untuk mendapatkan perkiraan sifat-sifat fisik dari material dan penentuan bentuk objek atau secara kuantitatif untuk mendefinisikan hubungan antara posisi kapal, posisi towfish, dan posisi objek.

Hasil interpretasi citra side scan sonar kemudian diidentifikasi sebagai objek yang diduga tinggalan arkeologi dan bukan tinggalan arkeologi. Objek tinggalan arkeologi kemudian dianalisis bersama dengan hasil survei tinggalan arkeologi darat di DAS Brantas, terutama di sepanjang Sungai Porong, serta hasil penelusuran arsip dan peta Belanda. Analisis ini dilakukan untuk mengetahui perkiraan kekunoan objek tinggalan arkeologi 
di dasar Sungai Porong yang ditangkap citranya melalui survei side scan sonar sehingga dapat diketahui konteks kesejarahan dari objek-objek tersebut.

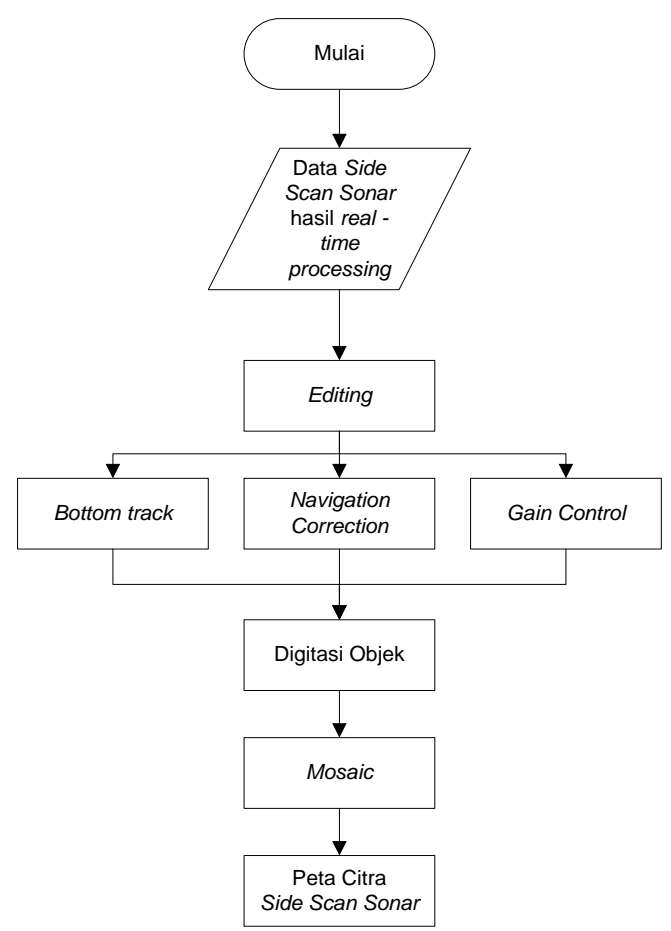

Sumber: Nugraha dan Yuwono 2014 dengan modifikasi penulis 2021

Gambar 3 Diagram Alir Pengolahan Data

\section{HASIL DAN PEMBAHASAN}

\section{Hasil Survei Side scan sonar}

Hasil pencitraan dasar perairan Sungai Porong diperoleh dari pengolahan data side scan sonar yang menunjukkan pola pengembalian gelombang yang kemudian menghasilkan bayangan objek yang berada di dasar sungai. Kontras antara bayangan objek dan permukaan substrat di sekitar objek tersebut memberikan gambaran tentang bentuk objek yang dideteksi.

Hasil citra side scan sonar menunjukkan bahwa sebagian besar dasar sungai di seluruh wilayah survei tertutup sedimen dengan tingkat refleksivitas rendah sampai menengah. Tingkat refleksivitas tersebut biasanya berasosiasi dengan sedimen dengan butiran halus sampai butiran agak keras. Diperkirakan sedimen di dasar sungai tersebut terdiri atas material lempung dan lanau. Gambaran umum citra Low to Moderate Reflectivity Sediment (LMRS) tersaji dalam Gambar 4.

Sejumlah depression (cekungan), mound (gundukan), serta sebaran batu-batu kecil ditemukan merata di area survei. Fitur-fitur tersebut terbentuk secara alami sebagai bagian dari proses transportasi sedimen dan aliran arus di sepanjang sungai. Proses sedimentasi sungai tersebut dapat mengakibatkan beberapa objek yang berada di bawah lapisan dasar sungai, terutama objek berukuran kecil dan menengah, akan sulit untuk diidentifikasi dan diinterpretasi.

Identifikasi sedimen dasar perairan melalui citra side scan sonar terkait erat dengan prinsip backscattering yang berhubungan dengan kekasaran sedimen (Gardner dkk 1991; Jackson dkk 1986, dalam Collier dan Brown 2005). Secara umum, daerah backscatter (hambur-balik) yang tinggi berhubungan dengan sedimen yang kasar, sedangkan daerah hambur-balik yang relatif rendah memiliki sedimen yang lebih halus. Sebagai contoh, permukaan lumpur halus dapat menghasilkan gelombang hambur-balik yang lemah, berbeda dengan permukaan bertekstur lebih keras, seperti pasir yang dapat memberikan pengembalian hambur-balik yang lebih kuat. Respon akustik tiap-tiap endapan permukaan sedimen dipengaruhi banyak faktor, di antaranya ukuran butir, skala kekasaran permukaan sedimen, dan variasi kemiringan yang signifikan (Urick 1983 dalam Ehrhold, 
Hamon, dan Guillaumont 2006). Amplitudo hambur-balik yang tinggi pada umumnya diwakili oleh gambaran yang lebih gelap pada rekaman, sedangkan nilai hambur-balik yang rendah ditunjukkan oleh gambaran yang lebih terang. Selain untuk membedakan ketampakan bentuk dasar perairan, prinsip backscatter akustik juga digunakan dalam survei side scan sonar untuk mengenali objek yang ada di dasar perairan.

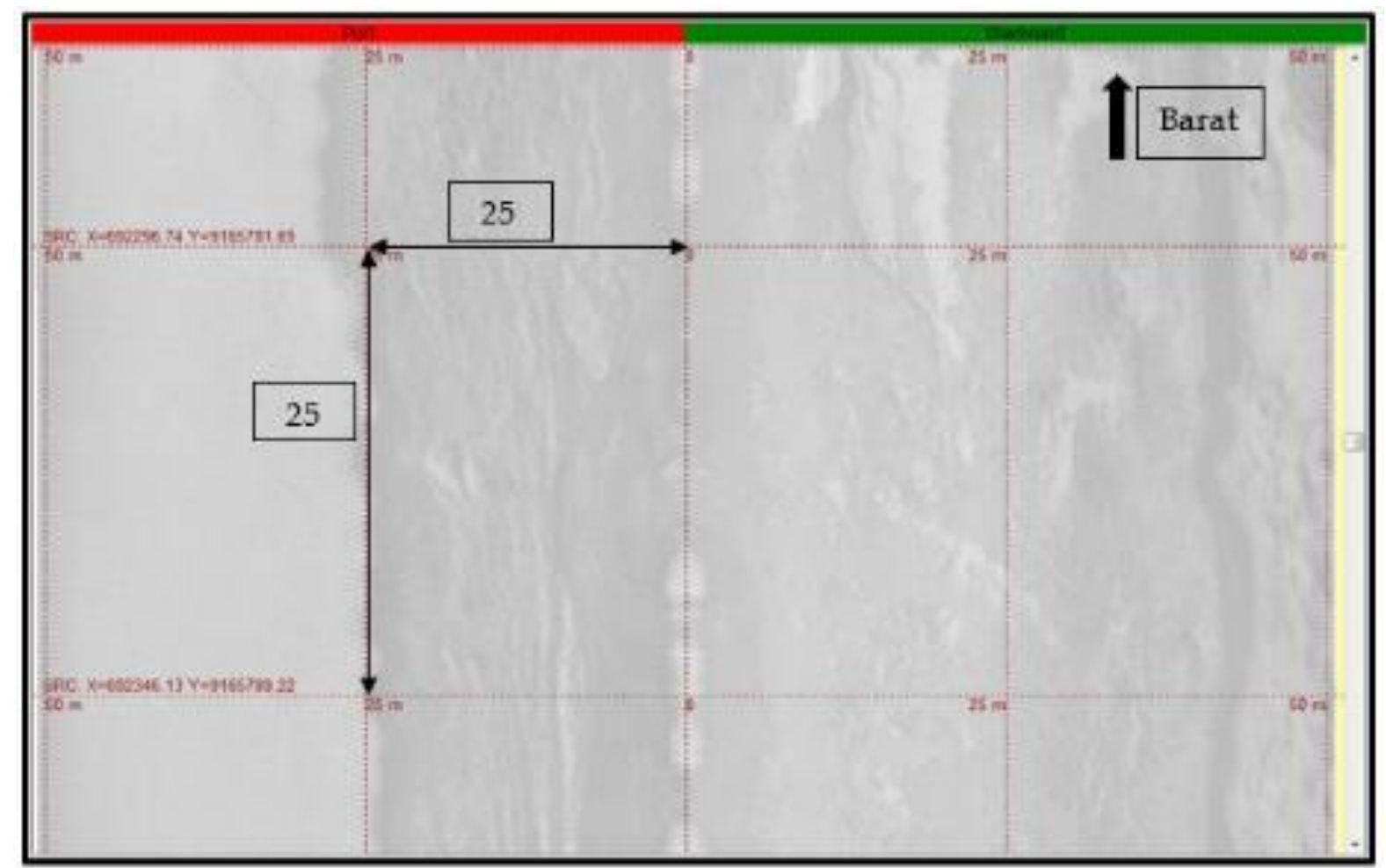

Sumber: Oseawan Geotama Surveindo 2019

Gambar 4 Gambaran Umum Citra Low to Moderate Reflectivity Sediment (LMRS)

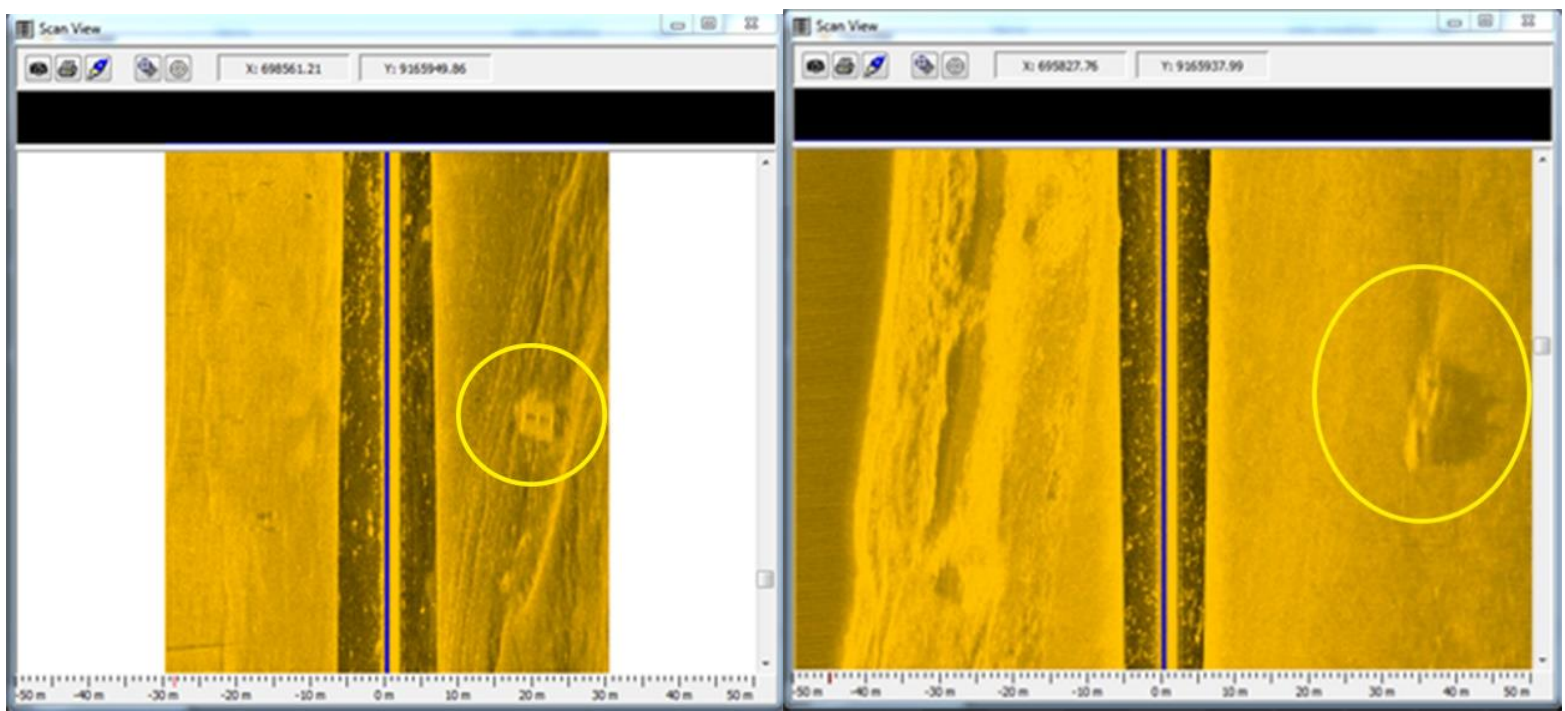

Sumber: Balai Arkeologi D.I. Yogyakarta 2019

Gambar 5 Beberapa Objek di Dasar Sungai yang Terekam dalam Survei

Selain sedimen dan batu-batu kecil, terdapat beberapa objek yang terverifikasi dari hasil identifikasi sebagai sonar contact (SC) (Gambar 5). Tabel 2 menampilkan koordinat dan keterangan sonar contact (SC) yang ditemukan dalam survei side scan sonar di area Sungai Brantas. Selain itu, terdapat juga satu sonar contact (SC) yang awalnya tidak teridentifikasi saat survei, tetapi ditemukan setelah data diproses dan dilakukan interpretasi. Sonar contact (SC) tersebut diidentifikasi sebagai objek yang diduga sebagai perahu kayu. Posisi 
sonar contact ini berada di koordinat Easting $703615.4 \mathrm{~m}$ dan Northing $9164947.8 \mathrm{~m}$. Berdasarkan dimensinya objek tersebut mempunyai dimensi panjang $\pm 4 \mathrm{~m}$, lebar $\pm 3 \mathrm{~m}$, dan tinggi $\pm 1 \mathrm{~m}$ (Gambar 6). Posisi sebaran sonar contact ditunjukkan dalam peta pada Gambar 7.

Sementara itu, berdasarkan akuisisi data batimetri dengan perangkat echosounder menunjukkan bahwa kedalaman Sungai Porong berkisar antara 0 hingga $7 \mathrm{~m}$ pada LWS (Lowest Water Spring). Rerata kedalaman Sungai Porong yang menjadi lokasi survei adalah 4-5 m pada LWS. LWS merujuk pada ketinggian permukaan air pada saat pasang surut terendah.

Tabel 2 Sonar Contact di Sungai Brantas

\begin{tabular}{lcll}
\hline Nama & Easting $(\mathbf{m})$ & Northing $(\mathbf{m})$ & \\
\hline SC 1 & 697292.37 & 9165844.35 & Keterangan \\
SC 2 & 704609.40 & 9166853.68 & Batu-Batu Kecil \\
SC 3 & 701667.14 & 9167102.20 & Riverbed yang berbentuk irregular \\
SC 4 & 701029.07 & 9166663.15 & Kumpulan Batu \\
SC 5 & 700543.50 & 9166292.81 & Batu-Batu Kecil \\
SC 6 & 698436.37 & 9165828.39 & Bekas garukan alat \\
SC 7 & 698278.17 & 9165808.87 & Jaring atau tali \\
SC 8 & 695799.35 & 9165857.36 & Bangkai perahu \\
SC 9 & 692972.13 & 9165854.35 & Objek yang berbentuk irregular \\
SC 10 & 695804.84 & 9165854.32 & Gundukan \\
SC 11 & 698585.68 & 9165907.71 & handmade dengan bentuk persegi \\
\hline
\end{tabular}

Sumber: Mochtar dkk 2019

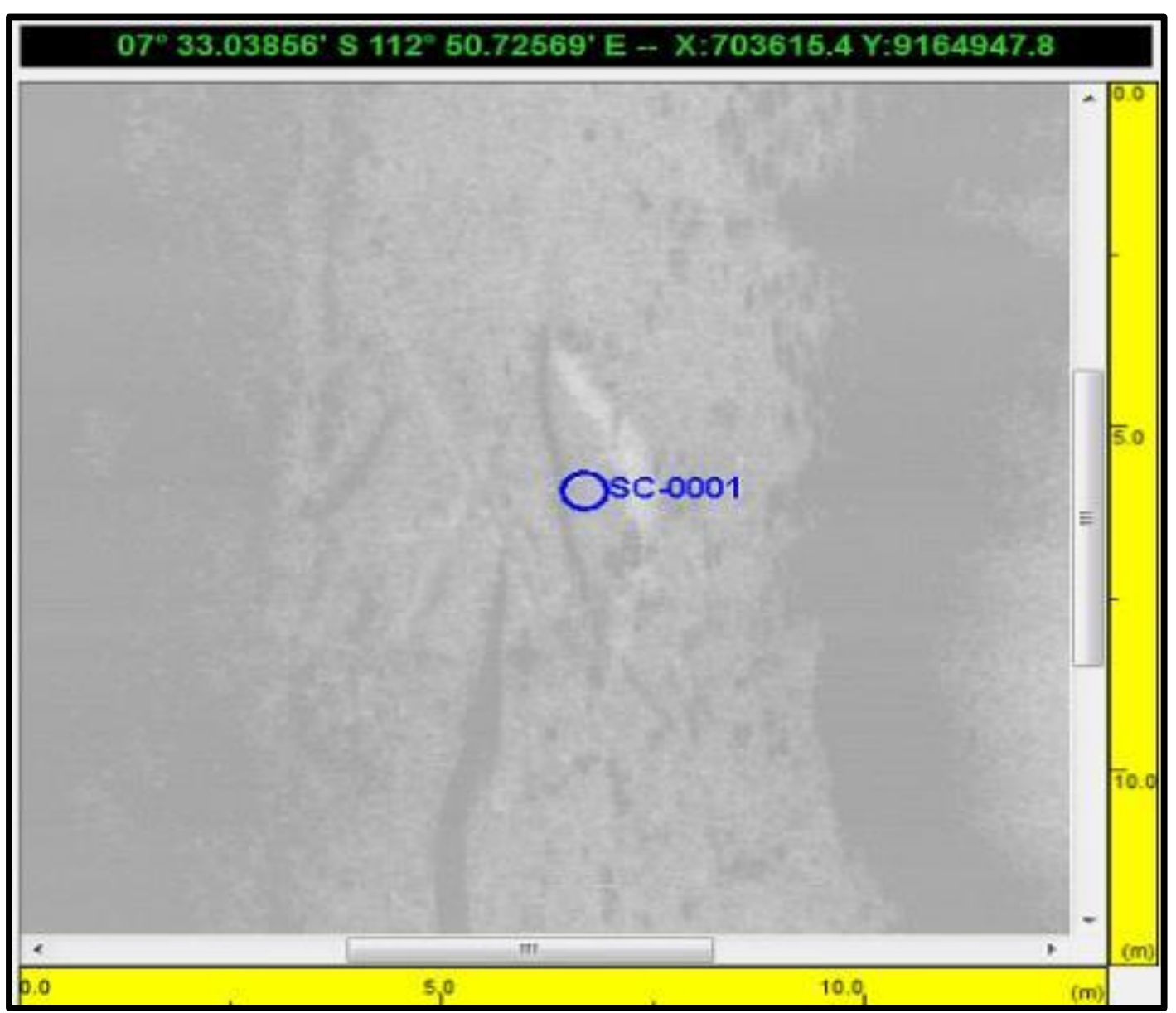

Sumber: Balai Arkeologi D.I. Yogyakarta 2019

Gambar 6 Sonar Contact Objek Bangkai Kapal 


\section{Konteks Kesejarahan Tinggalan Arkeologi di Dasar Sungai Brantas}

Survei dengan side scan sonar di hilir Sungai Brantas, tepatnya di bagian ujung Sungai Porong dilakukan berdasarkan beberapa pertimbangan. Sungai Brantas adalah sungai lama yang telah menjadi salah satu pusat aktivitas masyarakat Jawa Kuno, setidaknya sejak awal milenia kedua setelah Masehi. Sungai Brantas tidak hanya dimanfaatkan sebagai sumber air, tetapi juga sebagai jalur transportasi. Sumber tertulis menyebutkan bahwa Sungai Brantas merupakan sungai yang dapat dilayari hingga jauh ke wilayah hulunya (Christie 1982; Sandi dan Pamungkas 2015). Besar kemungkinan bahwa padatnya aktivitas masyarakat pada masa lalu tersebut meninggalkan jejak berupa benda-benda dari aktivitas tersebut di sepanjang aliran Sungai Brantas. Akan tetapi, hingga saat ini penelitian arkeologi terhadap tinggalan budaya materi tersebut masih jarang dilakukan. Hal ini dapat dipahami karena lokasi dan situasi wilayah perairan sungai yang tidak mudah untuk melaksanakan penelitian arkeologi.

Perkembangan arkeologi bawah air muncul sebagai salah satu solusi untuk dapat melaksanakan penelitian di Sungai Brantas. Akan tetapi, arkeologi bawah air sendiri masih terfokus pada penelitian di laut, belum banyak mengeksplorasi perairan sungai. Secara teoretis, tinggalan arkeologi di dasar Sungai Brantas dapat diteliti dengan menerapkan metode penelitian arkeologi bawah air, dengan melakukan survei dan/atau ekskavasi dengan penyelaman SCUBA (Self-contained Underwater Breathing Apparatus), atau bahkan SSBA (Surface-supplied Breathing Apparatus). Namun demikian, realitas lokasi penelitian tidak memungkinkan untuk dilakukannya observasi secara langsung dengan penyelaman.

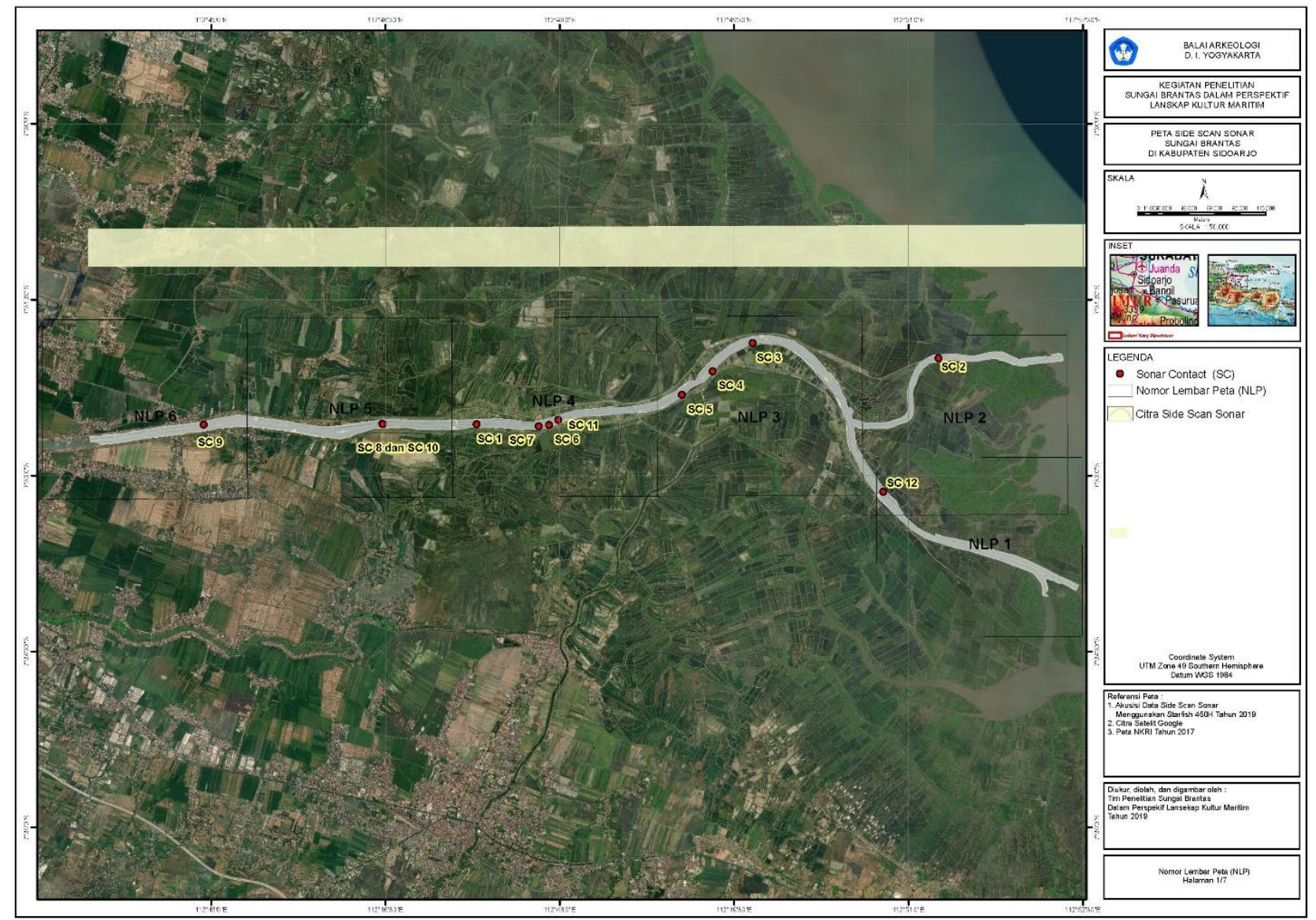

Sumber: Balai Arkeologi D.I. Yogyakarta 2019

Gambar 7 Sebaran Titik Sonar Contact

Sungai Porong yang menjadi lokasi penelitian ini adalah salah satu anak sungai dari Sungai Brantas yang bermuara di Selat Madura. Sungai Porong dipilih karena posisinya yang terhubung langsung dengan lautan luas karena fokus penelitian "Sungai Brantas dalam Perspektif Lanskap Kultur Maritim" adalah mempelajari peran 
Sungai Brantas dalam menghubungkan wilayah pedalaman dengan wilayah pesisir dan luar Jawa (Mochtar dkk 2019). Sayangnya, air di Sungai Porong sangat keruh dengan tingkat polusi yang tinggi, terutama setelah dijadikan alur buangan lumpur Lapindo. Kondisi ini menyebabkan Sungai Porong berisiko tinggi untuk diselami. Oleh karena itu, penelitian ini mengaplikasikan metode survei dengan side scan sonar untuk mengetahui potensi tinggalan arkeologi di dasar Porong tanpa perlu melakukan observasi langsung. Selain itu, survei side scan sonar mampu menyusur area survei yang luas dalam waktu yang lebih singkat, dibandingkan dengan metode survei arkeologi bawah air dengan penyelam.

Hasil survei dengan side scan sonar di sepanjang hilir Sungai Porong menunjukkan adanya beberapa objek di dasar sungai yang berpotensi sebagai tinggalan arkeologi. Dari dua belas objek terdeteksi, objek yang paling berpotensi sebagai jejak aktivitas masa lalu adalah objek kapal/perahu tenggelam. Sepanjang $10 \mathrm{~km}$ area survei, terdeteksi dua objek perahu tenggelam di dasar sungai. Akan tetapi informasi yang berhasil diperoleh hanya terbatas pada lokasi perahu tersebut dan perkiraan ukuran yang tampak di dasar sungai. Konfirmasi kekunoan perahu-perahu tersebut masih perlu dilakukan melalui penelitian lanjutan. Dengan demikian, memegang asumsi bahwa perahu-perahu tenggelam di dasar hilir Sungai Brantas berpotensi sebagai tinggalan arkeologi, perlu diuraikan konteks arkeologi dari wilayah yang disurvei dengan side scan sonar. Survei diawali dari ujung timur Sungai Porong, di daerah muara, menuju ke barat. Batas survei di sebelah barat berada di sekitar Jembatan Kalimati karena adanya struktur melintang yang dibangun di dasar sungai sehingga tidak dapat dilewati oleh perahu. Di dekat jembatan Kalimati tersebut terdapat suatu bangunan kecil yang oleh warga sekitar disebut rumah pompa. Pada salah satu sisi dinding luar dari bangunan ini terdapat tulisan angka tahun 1920 (Gambar 8).

Jembatan Kalimati dan rumah pompa termasuk dalam wilayah administratif Desa Pejarakan, Kecamatan Jabon, Kabupaten Sidoarjo. Rumah pompa merupakan bangunan pelindung dari tuas roda pemutar dari sistem pintu air di Jembatan Kalimati. Saat ini pintu air tersebut sudah tidak berfungsi lagi. Sistem pintu air ini dibangun untuk secara perlahan mengubah aliran sungai menjadi ke arah timur. Sebelumnya, aliran sungai berada di sisi selatan aliran saat ini dan berakhir di daerah Kalianyar, yang sekarang termasuk dalam wilayah Kabupaten Pasuruan. Jalur lama inilah yang disebut sebagai Kalimati oleh warga sekitar.

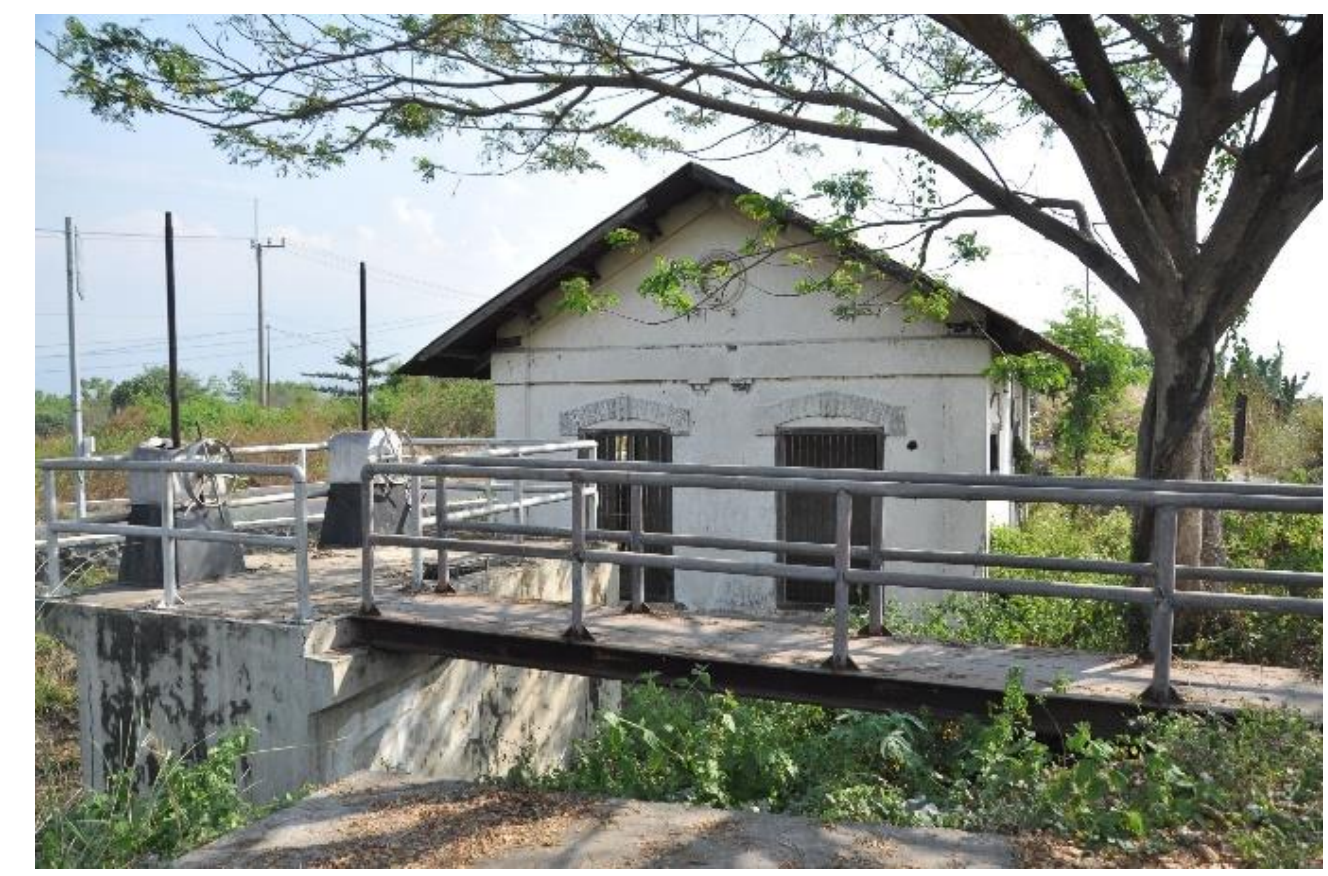

Sumber: Balai Arkeologi D.I. Yogyakarta 2019

Gambar 8 Bangunan Rumah Pompa

Kajian terhadap arsip dan peta kuno Belanda mengindikasikan bahwa pintu air di Desa Pejarakan yang saat ini disebut sebagai Jembatan Kalimati dibangun untuk mengaliri saluran irigasi yang pada peta tahun 1892 disebut sebagai "Porrong afwatering kanaal" (Gambar 9). Pada peta tersebut belum tampak adanya Jembatan Kalimati meski sudah terlihat adanya sebuah struktur melintang di pangkal saluran irigasi tersebut. Struktur 
inilah yang menyebabkan survei side scan sonar dalam penelitian ini tidak dapat dilanjutkan ke arah barat. Pintu air Jembatan Kalimati dan bangunan rumah pompa diperkirakan dibangun lebih kemudian pada tahun 1920. Dengan demikian, bangkai kapal dan tinggalan arkeologi lain yang ditemukan di dasar Sungai Porong sekarang kemungkinan besar diperkirakan dari periode pasca-1892.

Hingga kini belum diperoleh informasi yang komprehensif tentang kondisi lokasi survei pra-1892. Salah satu kemungkinan adalah saluran irigasi tersebut sebelumnya merupakan anak sungai yang telah ada sebelumnya yang kemudian diperlebar menjadi jalur utama. Sementara itu, kemungkinan lain adalah saluran tersebut memang sepenuhnya merupakan konstruksi baru yang dibangun oleh pemerintah kolonial Belanda.

Alasan pemindahan jalur sungai ini pun belum dapat diketahui secara konklusif. Sejak penetapan cultuur stelsel oleh pemerintah Hindia Belanda pada tahun 1830, wilayah Sidoarjo mengalami perubahan besar dengan dibukanya banyak perkebunan tebu yang merupakan salah satu komoditas yang diwajibkan dalam cultuur stelsel (Van Niel 1992; Permataasri, Antariksa, dan Siregar 2013). Setidaknya tercatat ada tiga belas pabrik gula didirikan di Sidoarjo sejak penetapan tanam paksa (Veriyanto 2015), sekarang hanya tinggal empat yang masih beroperasi. Sebagai konsekuensinya, diperlukan sistem irigasi yang baik untuk menopang produksi gula tersebut. Salah satu upaya yang dilakukan adalah dengan memanfaatkan jalur sungai untuk mengairi kanalkanal yang dibangun sebagai bagian dari sistem irigasi ini. Besar kemungkinan bahwa pemindahan jalur sungai di Sungai Porong sebagai hilir Sungai Brantas dilakukan sebagai respons pendukung sistem cultuur stelsel tersebut.

Survei arkeologi darat di sepanjang jalur baru ini belum memperoleh banyak informasi tentang kehidupan masa lalu di sana. Hal ini berkaitan dengan aktivitas penggunaan lahan di sepanjang bantaran sungai sebagai tambak-tambak ikan dan rumput laut sehingga menyulitkan untuk dilakukan survei arkeologi. Namun demikian, berdasarkan bukti sejarah, daerah sepanjang hilir Sungai Brantas cabang Sungai Porong ini diperkirakan dahulu merupakan wilayah Kerajaan Panjalu yang dibentuk pada abad ke-11 M sebagai salah satu pecahan dari Kerajaan Airlangga (Robson 1995).

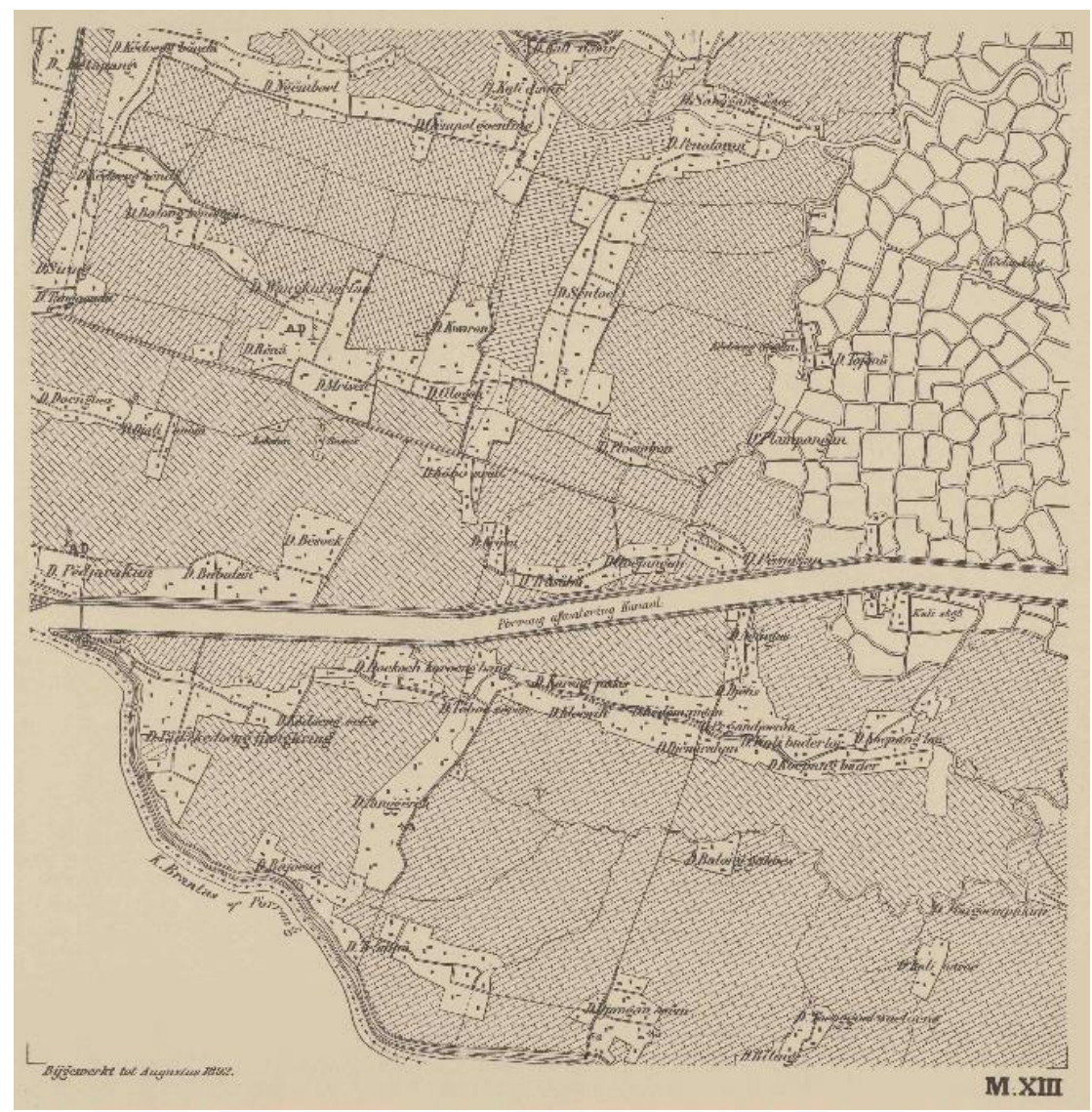

Sumber: KITLV

Gambar 9 Aliran Sungai Porong Lama Tahun 1892 


\section{Penerapan Survei Side Scan Sonar untuk Arkeologi Bawah Air di Perairan Sungai}

Survei side scan sonar di Sungai Porong sebagai ujung hilir Sungai Brantas dilaksanakan untuk mengumpulkan data arkeologi bawah air yang berada di dasar sungai. Survei arkeologi dengan metode geofisika ini dipilih setelah mempertimbangkan situasi lokasi survei yang tidak memungkinkan untuk penerapan metode pengumpulan data dengan observasi langsung melalui penyelaman. Side scan sonar memungkinkan tim peneliti melihat objek yang berada di dasar sungai untuk kemudian menelusuri objek yang diperkirakan sebagai tinggalan arkeologi.

Penggunaan side scan sonar dalam kegiatan survei tinggalan arkeologi bawah air bukan merupakan hal yang baru (Green 2004; Wynn 1986). Pada banyak penelitian perangkat side scan sonar yang digunakan telah mampu memberikan citra dengan resolusi yang tinggi sehingga objek yang terdapat di dasar perairan dapat terlihat jelas hingga komponen-kompenen berukuran kecil. Pengembangan penggunaan metode geofisika dalam penelitian arkeologi bawah air diawali dengan pemahaman terhadap keterbatasan metode penyelaman untuk menjangkau objek di dasar laut yang memiliki kondisi berbeda-beda. Beberapa faktor yang menghambat dilakukannya penyelaman di suatu lokasi penelitian adalah posisi objek berada di kedalaman lebih dari $40 \mathrm{~m}$, arus kencang, tingkat visibilitas rendah, dan/atau tingkat polusi air yang tinggi.

Penerapan survei side scan sonar di hilir Sungai Brantas dilakukan dengan sistem trial and error. Seperti pada penelitian arkeologi bawah air pada umumnya, penggunaan side scan sonar dan metode geofisika lainnya masih dominan digunakan di wilayah laut dan belum banyak digunakan di perairan sungai. Hal ini menyebabkan sedikitnya referensi yang bisa diacu untuk penerapan metode tersebut di lapangan. Selain itu, tentunya kondisi setiap lokasi penelitian memiliki keunikan yang terkadang membutuhkan kreativitas tim peneliti untuk menerapkan suatu metode pengambilan data. Dalam konteks penelitian ini, jalur sungai yang berupa jalur perairan sempit, dibanding dengan laut, memberikan tantangan tersendiri dalam pelaksanaan survei.

Survei dilaksanakan menggunakan satu perahu kecil milik warga sekitar yang sengaja dipilih untuk mempermudah manuver di sungai. Sungai Porong sebagai lokasi survei merupakan sungai yang lebar hingga mencapai $200 \mathrm{~m}$ sehingga pemilihan perahu tersebut cukup ideal untuk menyusuri sungai dan mencakupi seluruh sisi lebar sungai. Perahu dijalankan dengan kecepatan rendah untuk menjamin bahwa perangkat transducer yang terendam di air menangkap pantulan gelombang dari dasar sungai secara optimal. Perangkat transducer diikat pada sisi starboard perahu untuk menjaga agar tidak menabrak dermaga atau bantaran sungai. Perangkat ini dipasang minimal sejajar dengan lunas perahu agar gelombang yang dipancarkan tidak menabrak lunas dan menimbulkan bias. Pada lokasi survei di perairan dalam, perangkat ini dapat dipasang setidaknya 1 hingga $1,5 \mathrm{~m}$ di bawah lunas. Akan tetapi, pada penelitian ini hal tersebut tidak dapat dilakukan karena kedalaman sungai bervariasi dengan titik terdangkal sekitar $1,5 \mathrm{~m}$.

Alat side scan sonar yang digunakan dalam penelitian ini, Starfish $450 \mathrm{H}$, memberikan hasil yang cukup maksimal. Pemilihan alat tipe ini didasari oleh beberapa pertimbangan, di antaranya anggaran penelitian dan lokasi penelitian. Tipe ini merupakan jenis yang tepat untuk digunakan untuk survei area sungai yang kedalamannya kurang dari $10 \mathrm{~m}$ dan selisih kedalaman mencapai lebih dari $5 \mathrm{~m}$ karena bisa diikatkan pada sisi starboard perahu survei sehingga tidak akan menabrak dasar sungai. Sebagai perbandingan, side scan sonar tipe Starfish 4530EM menggunakan towed-fish dengan ukuran cukup besar, mendekati $50 \mathrm{~cm}$, hingga tidak mungkin untuk diikatkan pada lambung perahu dan harus ditarik dari buritan perahu. Apabila survei dilakukan di laut, tidak akan ditemukan banyak permasalahan untuk operasional alat ini. Akan tetapi, lingkungan sungai akan menyulitkan untuk menjaga supaya alat tidak menabrak dasar sungai, atau bahkan objek keras yang berada di dasar sungai.

Hasil citra yang dihasilkan dalam survei side scan sonar belum cukup memberikan citra dengan resolusi terbaik. Beberapa faktor penyebabnya adalah adanya gambaran proses sedimentasi sungai dan jenis sedimen di dasar sungai yang cenderung bertekstur lembut sehingga memantulkan sonar (backscatter) yang lemah. Hal ini menyebabkan munculnya kesulitan pada saat melakukan identifikasi objek yang terekam dalam data hasil survei. Selain itu, dengan besaran resolusi ini, cukup sulit untuk dilakukan identifikasi objek-objek yang berukuran kecil, ataupun bagian-bagian detail pada sebuah objek yang ukurannya cukup besar untuk diidentifikasi. 


\section{PENUTUP}

Penelitian lanskap kultur maritim di Sungai Brantas dilaksanakan dengan tujuan untuk mempelajari konsep keruangan yang diterapkan masyarakat pada masa lalu di tempat mereka beraktivitas, konsep yang memandang lautan sebagai kelanjutan dari daratan. Dalam konsep kognitif ini, sungai menjadi salah satu penghubung terbentuknya hubungan antara daratan dan lautan. Sungai tidak hanya berfungsi sebagai sumber air untuk menunjang kehidupan keseharian mereka, tetapi juga sebagai jalur transportasi, baik orang maupun barang dari hilir ke hulu, dan sebaliknya.

Sungai Brantas adalah sungai terpanjang kedua di Pulau Jawa, setelah Bengawan Solo. Hulunya berada di daerah Malang dan hilirnya bercabang di Mojokerto, satu cabang menjadi Sungai Mas yang bermuara di Surabaya dan yang lain menjadi Sungai Porong yang bermuara di Sidoarjo. Sungai Brantas telah menjadi salah satu pendukung utama terbentuknya kebudayaan di sepanjang alirannya sejak zaman kerajaan lebih dari seribu tahun yang lalu. Namun demikian, penelitian tentang peran sungai ini dalam mendukung hubungan wilayah pedalaman dengan pesisir masih jarang dilakukan. Maka penelitian ini berfokus pada wilayah hilir Sungai Brantas, khususnya di cabang Sungai Porong.

Penelitian tentang tinggalan arkeologi di Sungai Porong dilakukan dengan metode survei side scan sonar karena lokasinya tidak memungkinkan untuk dilaksanakannya metode survei arkeologi bawah air dengan penyelaman. Berdasarkan hasil survei dan analisis data yang diperoleh, diketahui bahwa dasar Sungai Porong didominasi oleh Low to Moderate Reflectivity Sediment (LMRS) berupa lempung dan lanau. Sedimen tersebut diperkirakan merupakan sisa dari luapan lumpur Lapindo yang dibuang ke Sungai Porong. Kontur dasar sungai terdiri dari linear debris, riverbed depression (cekungan), dan mound (gundukan) serta batu-batu kecil. Survei side scan sonar ini juga berhasil merekam objek yang teridentifikasi dan terinterpretasi sebagai bangkai kapal.

Penggunaan metode geofisika dengan perangkat side scan sonar dalam penelitian ini menunjukkan tingkat efisiensi yang cukup hingga tinggi karena mampu memberikan data awal kondisi dasar perairan sungai tanpa perlu melakukan penyelaman. Hal ini menunjukkan bahwa metode survei ini selain bisa diterapkan di laut, dapat diterapkan di sungai. Meski demikian, diperlukan kecermatan dalam pelaksanaan survei di perairan sungai yang memiliki karakter yang berbeda dengan perairan laut.

Meski berhasil menyajikan data potensi tinggalan arkeologi bawah air, penggunaan metode survei side scan sonar tetap memerlukan penelitian lanjutan citra side scan sonar mampu memperlihatkan ketampakan permukaan dasar sungai yang cukup jelas sehingga sangat baik digunakan untuk interpretasi panjang dan tinggi suatu objek. Namun, pada penelitian selanjutnya dapat difokuskan pada beberapa sonar contact objek yang ditemukan untuk lebih memastikan objek tersebut. Ketika penyelaman tidak dapat dilakukan, penelitian dengan bantuan alat teknologi lain seperti ROV perlu dilakukan untuk mengonfirmasi konteks arkeologi dari objek yang terdokumentasi dalam survei side scan sonar.

\section{UCAPAN TERIMA KASIH}

Para penulis menyampaikan terima kasih kepada seluruh anggota tim penelitian Maritim Brantas Balai Arkeologi Provinsi D.I. Yogyakarta tahun 2019 serta Dinas Pendidikan dan Kebudayaan Kabupaten Sidoarjo, Camat Jabon, dan Pokdarwis Wisata Bahari Tlocor yang telah mendukung pelaksanaan penelitian ini. Ucapan terima kasih juga disampaikan kepada Bapak Buasan dan Bapak Rohmad, para nahkoda perahu yang telah mendukung proses akuisisi data survei side scan sonar dalam penelitian ini.

\section{PERNYATAAN PENULIS}

Artikel ini merupakan salah satu keluaran dari penelitian arkeologi berjudul "Sungai Brantas dalam Perspektif Lanskap Maritim" yang dilaksanakan dengan skema SBK 2019 oleh Balai Arkeologi Provinsi D.I. Yogyakarta. Ketiga penulis dalam artikel ini adalah kontributor utama yang memberikan kontribusi dengan porsi yang sama dalam penyusunan artikel ini. 


\section{DAFTAR PUSTAKA}

Bartholomä, Alexander. 2006. "Acoustic bottom detection and seabed classification in the German Bight, southern North Sea." Geo-Marine Letters 26(3):177-84.

Christie, Jan Wiseman. 1982. "Patterns of Trade in western Indonesia: Ninth through Thirteenth Centuries A.D." University of London.

Coiras, E. dan J. Groen. 2009. "Simulation and 3D Reconstruction of Side-Looking Sonar Images." Hal. 1-14 in Advances in Sonar Technology, diedit oleh S. R. Silva. I-Tech Education and Publishing.

Collier, J. S. dan C. J. Brown. 2005. "Correlation of sidescan backscatter with grain size distribution of surficial seabed sediments." Marine Geology 214:431-49.

Dillenia, Ira dan Rainer Arief Troa. 2016. "Identifikasi Situs Kapal Karam Bersejarah 'Karang Panjang' di Perairan Pulau Laut Natuna." Jurnal Kelautan Nasional 11(1):20.

Ehrhold, Axel, Dominique Hamon, dan Brigitte Guillaumont. 2006. "The REBENT monitoring network, a spatially integrated, acoustic approach to surveying nearshore macrobenthic habitats: application to the Bay of Concarneau (South Brittany, France)." ICES Journal of Marine Science 63(9):1604-15.

Flemming, B. W. 1976. "Side-Scan Sonar : A Practical Guide." The International Hydrographic Review 53(1):6592.

Gemilang, Wisnu Arya, Nia Naelul Hasanah Ridwan, Ulung Jantama Wisha, Guntur Adhi Rahmawan, dan Zainab Tahir. 2020. "Identifikasi Awal Potensi Tinggalan Budaya Bawah Laut Kalimantan Barat, Berdasarkan Data Side Scan Sonar." Jurnal Kelautan Nasional 15(1):13-22.

Green, Jeremy. 2004. Maritime Archaeology: A Technical Handbook, Second Edition. Elsevier.

Hansen, Roy Edgar. 2011. "Introduction to Synthetic Aperture Sonar." Hal. 3-28 in Sonar System, diedit oleh N. Kolev. Rijeka: IntechOpen.

Hedwi, P. 2014. "Transportasi Air dalam Perdagangan pada Masa Jawa Kuno." Forum Arkeologi 27(3):155-74.

Hobbs, CH, DB Blanton, RA Gammisch, dan J. Broadwater. 1994. "A marine archaeological reconnaissance using side-scan sonar, Jamestown Island, Virginia, USA." Journal of Coastal Research 10(2):351-59.

Hosty, K., J. Hunter, dan S. Adhityatama. 2018. "Death by a Thousand Cuts: An Archaeological Assessment of Souveniring and Salvage on the Australian Cruiser HMAS Perth (I)." International Journal of Nautical Archaeology 47(2).

Manik, Henry M. 2011. "Underwater Acoustic Detection and Signal Processing Near the Seabed." Hal. Ch.12 in Sonar System, diedit oleh N. Kolev. Rijeka: IntechOpen.

McCauley, R. D. dan J. P. Siwabessy. 2005. Coastal Zone CRC-Coastal Water Habitat Mapping-Shallow Water Assessment Technologies. Perth.

Mochtar, Agni Sesaria, Hery Priswanto, Shinatria Adhityatama, Wastu Hari Prasetyo, Muslim Dimas Khoiru Dhonny, Shoim Abdul Aziz, Ghusnul Assa Fuadillah, Putu Bagus Aditya Asmaranatha, Pahadi, Vicky Narendra Pharayogi, dan Nabila Ni'maturrachmah. 2019. Laporan Penelitian Arkeologi: Sungai Brantas dalam Perspektif Lanskap Kultur Maritim. Yogyakarta.

Nugraha, I Made Dwiva Satya dan Yuwono. 2014. "Studi Aplikasi Multibeam Echosounder dan Side Scan Sonar untuk Mendeteksi Free Span pada Saluran Pipa Bawah Laut." GEOID 10(1):65-69.

Permataasri, W. G., Antariksa, dan J. P. Siregar. 2013. "Pelestarian Kawasan Pabrik Gula Watoe Toelis Sidoarjo." Arsitektur e-Journal 6(2):115-29.

Robson, S. 1995. Desawarnana (Nagarakrtagama) by Mpu Prapanca. Leiden: KITLV.

Sandi, A. D. dan Y. H. Pamungkas. 2015. "Banjir Sungai Brantas Masa Raja Airlangga Abad XI, Berdasarkan Prasasti Kamalagyan 1037 M." Avatara, e-Journal Pendidikan Sejarah 3(1):50-57.

Singh, Hanumant, Jonathan Adams, David Mindell, dan Brendan Foley. 2000. "Imaging Underwater for Archaeology." Journal of Field Archaeology 27(3):328.

Staniforth, Mark. 2009. "Research in Underwater Archaeology: some challenges and approaches for the future." Freiberg Online Geology 22:106-9.

Van Niel, Robert. 1992. Java Under the Cultivation System. Leiden: KITLV Press.

Veriyanto, M. 2015. "Perkembangan Industri Gula di Kabupaten Sidoarjo Tahun 1859-1900." Universiyas Negeri Yogyakarta. 
Survei Side Scan Sonar dalam Penelitian Arkeologi Bawah Air di Perairan Sungai: Studi Kasus di Daerah Aliran Sungai Brantas Agni Sesaria Mochtar, Firman Setiawan, dan Shinatria Adityatama (99-112)

Doi: $10.24832 / n w . v 15 i 2.459$

Westerdahl, C. 1992. "The Maritime Cultural Landscape." The International Journal of Nautical Archaeology 21(1):5-14.

Wijonarko, W. W. dan B. Sasmito. 2016. "Kajian Pemodelan Dasar Laut Menggunakan Side Scan Sonar Dan Singlebeam Echosounder." Jurnal Geodesi Undip 5(2):168-78.

Wynn, Jeffrey C. 1986. "A review of geophysical methods used in archaeology." Geoarchaeology 1(3):245-57.

Yuniar, D. W., T. W. Suharso, dan G. Prayitno. 2010. "Arahan Pemanfaatan Ruang Pesisir Terkait Percemaran Kali Porong." Jurnal Tata Kota dan Daerah 2(2):63-74. 